Volume 13

Issue 1 Revisiting the Life and Work of Raphaël

Lemkin

Article 18

4-2019

\title{
Book Review: Concentration Camps: A Short History
}

Mackenzie Lake

Friedrich-Schiller-University Jena

Follow this and additional works at: https://digitalcommons.usf.edu/gsp

\section{Recommended Citation}

Lake, Mackenzie (2019) "Book Review: Concentration Camps: A Short History," Genocide Studies and Prevention: An International Journal: Vol. 13: Iss. 1: 195-196.

DOI:

https://doi.org/10.5038/1911-9933.13.1.1635

Available at: https://digitalcommons.usf.edu/gsp/vol13/iss1/18

This Book Review is brought to you for free and open access by the Open Access Journals at Digital Commons @ University of South Florida. It has been accepted for inclusion in Genocide Studies and Prevention: An International Journal by an authorized editor of Digital Commons @ University of South Florida. For more information, please contact digitalcommons@usf.edu. 


\title{
Book Review: Concentration Camps: A Short History
}

\author{
Mackenzie Lake \\ Friedrich-Schiller-University Jena \\ Jena, Germany
}

Concentration Camps: A Short History

Dan Stone

Oxford, Oxford University Press, 2017

159 pages; Price: \$16.95 Hardcover

Reviewed by Mackenzie Lake

Friedrich-Schiller-University Jena, Germany

In Concentration Camps: A Short History, Dan Stone discusses the different concentration camps of the modern world. There are few books that combine the early colonial concentration camps, the Nazi concentration camps, the Soviet Gulag, the American internment camps for Japanese citizens, and the postwar Soviet camps all together under the same term: concentration camp. Stone does so cautiously, taking care not to claim that all these camps were the same. Instead, he looks at the different concentration camps over time to show that, whether one wishes to accept it or not, concentration camps have been an ever-present reality throughout all political systems of modernity. The discussion and comparison of the different camp systems he places together throughout the book is very thought-provoking, forcing the reader to question for himself the nature of concentration camps and the role they played and continue to play in society.

The book begins with a discussion of the term concentration camp. For this, Stone looks to the definition given in 1945 by journalist Patrick Gordon Walker that he finds limiting. This first chapter is a critique of this understanding of a concentration camp. Unlike Gordon Walker, Stone claims a concentration camp does not have to look like those of the National Socialists. This point is built upon the various examples of concentration camps throughout modern history both inside and outside of Nazi Germany in the following chapters. Alongside Gordon Walker, Stone looks to Hannah Arendt to define what can be called a concentration camp, critiquing the distinction she makes between the Nazi and Soviet camps. Stone presents his own working definition of concentration camps that he will refer to and challenge throughout the book.

After challenging these distinct definitions of concentration camps and offering a broader understanding of the term, Stone uses concrete historical examples to support his broader definition of a concentration camp that suggests such camps do not have to be surrounded by barbed wire to fall under this category. He looks first at what he calls, proto-concentration camps, in America and Australia designed to segregate the indigenous population. These early camps, according to Stone, are the beginning of the development of modern concentration camps. The first of these concentration camps he addresses are those set up in Cuba and South Africa as well as concentration camps developed in colonial settings. Throughout the discussion of the conditions of these early camps, he includes critique of historians' understanding of the term concentration camp.

In order to define what can be considered a concentration camp, Stone includes a discussion of internment camps that are not concentration camps. The only reason Stone claims why these camps cannot be considered concentration camps is because they held soldiers instead of civilians, not because the conditions were better than the other camps mentioned in the book. Despite this difference, the POW camps added to the development of concentration camps. Along with the POW camps during WWI, the internment of civilians during this war was widespread and shaped the concentration camps that would exist during the next war. He presents the concentration camps of the Ottoman Empire through the eyes of historians as an example of the connection concentration camps can have to genocide.

After establishing the origins of concentration camps, the book continues to discuss the camps that come to mind most often when using the term. What makes this discussion of the Nazi 
concentration camps unique is Stone's use of early accounts of the concentration camps, such as the book published by German journalist Stefen Lorent, published in the UK in 1940 about his experience of Nazi persecution in 1933. He also discusses the importance of camps in general to the Nazi society. The following chapter discusses the Soviet concentration camps. This chapter focuses on the differences amongst the different types of these camps. Unlike the Nazi camps, there is no single image that comes into mind when one thinks about the Gulag. This is one reason why it is so difficult to use the term concentration camp for such camps because this creates a misleading idea of what the Soviet camps were. Yet, Stone continues to use the term in order to argue that concentration camps are a defining element of modern society, regardless of the political order.

Chapter 5 places the Nazi camps in comparison to other concentration camps that existed throughout the war, albeit somewhat provocatively. He never settles on a position whether these other camps should be considered also under the term concentration camps. Here, he discusses the camps in Italy under Mussolini and in Spain under Franco. Perhaps the most provocative accounts mentioned in this chapter refer to the internment camps in the United States and Britain. While explicitly stating that these camps differed greatly from the others mentioned in the book, Stone places these camps alongside the others mentioned in the book to show that even democratic nations were not unwilling to turn to such internment of civilians during wartime and even after the war through the establishment of Displaced Person (DP) camps. Here, it seems that Stone draws the line in his broader understanding of the term concentration camp. He would not consider the DP camps existing following the war as concentration camps. This is, according to Stone, because the people interned in these camps, unlike in those mentioned in the other chapters throughout the book, still had legal representation and rights. The chapter continues to look at other camps existing after the war that can be considered concentration camps to show the continued development of this concept of concentration camps even after the liberation of Auschwitz. The camps mentioned here are the Communist concentration camps, Latin American camps, and Bosnian.

The final chapter is where Stone moves on to discuss what the diversity of these concentration camps that exist throughout the world in all modern political contexts tells us, if anything, about the nature of modernity itself. In order to answer this question, he looks to the theories of both sociologists and philosophers to analyze their understanding of what modern concentration camps mean for society. This discussion is left open-ended, provoking the reader to question the nature of modernity for himself with the idea of concentration camps in mind. Taking a somewhat pessimistic stance, Stone presents the concentration camps as an element of modernity that cannot be escaped. Though he admits that more people around the world are not interned in camps, he also suggests that it could be the case that one may fall into such a camp. Overall, Stone raises more questions with this book then he answers, but this, it seems is exactly his intent. Students will read this book and be left to question the nature of a concentration camp and what the existence of such camps around the world under differing political systems can say about modernity. For Stone, the exact terminology is less important than the development of such camps and showing that this development did not end after WWII, but continues today. Along with provoking questions regarding the nature of modernity, Stone's book presents a very scary point: concentration camps can exist anywhere under any type of political society and anyone can become the target of such a camp. 